\section{Trevor Thomas Griffiths}

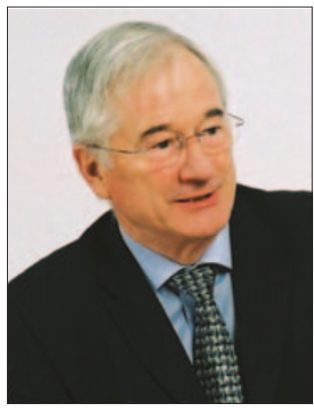

The death of Trevor Griffiths on 19 February 2006 deprived the profession and the community in which he lived of a man whose contributions to life it is difficult to fully account.

A former pupil of the Howardian High School in Cardiff, Trevor entered the newly founded Cardiff Dental School in its first intake of students and graduated in 1968. His early career took him to Swansea as an SHO, back to the Dental School where he was a lecturer in conservative dentistry and then to Gwent to work in the Community Dental Service as an SDO. In the mid 1970s Trevor established a practice in Cardigan.

During the 20 years that he ran his practice, before ill health forced his retirement, Trevor had become a champion for his local community. For many years he was both a town and county councillor, becoming Mayor of Cardigan in 2000.

Trevor also had a lifelong passion for singing and sang with a number of local choirs and the operatic society. (He once appeared at BDA Welsh Council almost unrecognisable, sporting a beard - a necessary prop for his next operatic appearance!) He was also a member of a small brass ensemble in Cardigan where he played the clarinet and tuba.

Trevor also remained fully committed to the practice of NHS dentistry. His own postgraduate interests were wider than general dental practice and included the attainment of a Masters Degree in Law in 1989 and in Public Health in 1997. He had been awarded a DGDP and was a GDC visitor to the examination for membership of the Faculty of General Dental Practitioners.

\section{Gordon Denner Brown}

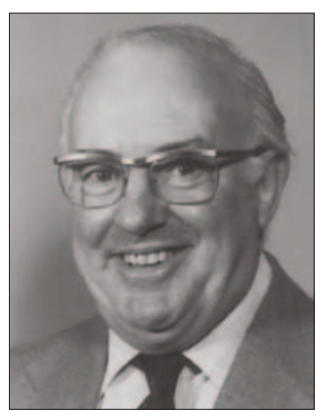

It is with regret that we record the death of Gordon Denner Brown who died on 24 March 2006 when on holiday at his home in Majorca.

He was one of the most respected dental surgeons in South Wales. After qualifying in Dental Surgery at Bristol Dental School in 1946 and serving as Junior and Senior House Officer, he joined his father in general dental practice in Cardiff.

When the University of Wales Dental School was opened in 1965 he was appointed a part-time lecturer in the Department of Periodontology. He also served as Chief Administrative Dental Officer for Mid Glamorgan Health Authority until retirement in 1992.

He was elected to the Board of the British Dental Association in 1952 and served as Honorary Secretary to the South Wales and Monmouthshire Branch of the British Dental Association for over 33 years. For his services to dentistry he was elected a Fellow of the Association in 1984.

He served on the BDA Council, the Central Committee for University Dental Teachers and Research Workers, the Auxillary Personnel Committee, the General Dental Services Committee, the Membership and Ethics Committee and Disciplinary Committee
He once appeared at BDA Welsh Council sporting a beard - a necessary prop for his next operatic appearance!

There were also achievements in the UK arena. He became the GDC member from Wales in 1991; he made major contributions to the development of the 'Fitness to practise' procedures and was also the GDC nominee to the UK Inter-professional Group of which he was the Chair for a short time.

With all his wide interests Trevor did not neglect the profession in Wales, amongst whom he was very highly regarded. He was a member of the Welsh Dental Committee and later the Welsh Assembly Government and for a while was its Chair. He was an active member of the BDA in Wales and a co-opted member to BDA Welsh Council. In recognition of his services to dentistry the University of Wales awarded Trevor an Honorary Fellowship in 2002 and for his wider UK services he was made MBE in 2004.

His funeral service, held in the Chapel adjacent to his former practice in Cardigan and attended by over 600 people, heard tributes to him from both the profession and the local community, giving to each group glimpses of his life. The singing and the brass ensemble accompaniment during the service was a fitting tribute to the life of a man who made a difference.

To Meifis, his wife and to Elis, his son we send not only our condolences but also our thanks for sharing him with us. It was a privilege to have known Trevor.

P. L., S. G.

\section{He was one of the most respected dental surgeons in South Wales.}

and the BDA Reorganisation Committee. Outside the Association he served and represented the Profession on the Standing Dental Advisory Committee, the Dental Formulary Sub-Committee and the National Joint Council for the Craft of Dental Technicians.

In 1972 Gordon considered it to be a great honour to be asked by the Secretary of State for Wales to become a Member of the Steering Committee for the Reorganisation of the National Health Service in Wales. He was a Member of Federation Dentaire International, the British Society of Periodontology and National Association of Administrative Dental Officers.

His non-professional activities included Membership and Past President of the Rotary Club of Cardiff East, Honorary Secretary of Penarth Civic Society and Member of the Cardiff North Conservative Association. He also enjoyed Membership of Glamorgan Golf Club, Penarth Yacht Club and Sully Sailing Club.

Gordon will be sadly missed by all his friends and we extend our sincere condolences to his wife, Mildred, son Richard and daughter Susan and their families. 